Journal of Economics and Behavioral Studies

Vol. 4, No. 12, pp. 691-702, Dec 2012 (ISSN: 2220-6140)

\title{
Financial Determinants of Bank Performance in Taiwan
}

\author{
Yu-Ting Huang1, ${ }^{1}$ Shiow-Ying Wen, ${ }^{2}$ Jean Yu \\ ${ }^{1}$ Chang Gung University, Taiwan \\ ${ }^{2}$ National Chiayi University, Taiwan \\ *wensy@mail.cgu.edu.tw
}

\begin{abstract}
As the consolidation of financial institutions is one of the highlights in recent financial territory, we examine whether banks being subordinated under the financial holding company (FHCs) outperform to independent banks in Taiwan, covering 15 FHCs banks and 18 independent banks in our sample for the period from 2005 to 2010. Using the CAMEL approach, we also investigate empirically further the financial determinants of banks' performance regarding FHCs banks and independent banks respectively, and examine whether the financial determinants of banks' performance differ before and after the financial crisis. Results show that ROA is strongly related to certain CAMEL ratios, such as the total capital ratio, loan loss reserve/gross loans, the burden ratio, and net interest income divided by total assets. Moreover, the positive significant capital adequacy ratio in the post-crisis period in our sample is mainly driven by subordinated banks. Finally, asset quality factor has explaining power for the pre-crisis and post-crisis periods, meaning prevention safety net built predominantly in refraining from external shocks.
\end{abstract}

Keywords: Financial holding company, CAMEL approach, financial crisis, banking industry, market structure.

\section{Introduction}

The establishment of financial holding companies (FHCs) could promote economies of scale and enable the banking sector to compete more efficiently. With most of countries having a bank-based financial system, it virtually draws attention on determining factors for profitability in the banking sector. In Taiwan, how to make optimal use of the resources available and improve operational efficiency remains challenge. Research on determinants of bank profitability is extensive. However, little is known about the Taiwanese banking system due to the relative numerous and small, size of FHCs, yet complete diversified structure in Taiwan compared to other Asian countries. For example, the three largest banks in both Hong Kong and Singapore have a total market share of more than 80\%, whereas none of the 15 FHCs in Taiwan have a market share of more than $10 \%$. Before the 1990s, Taiwan's financial sector was subject to government relations, and all banks were either owned or partly owned by the government. Since then, the financial sector began its reform towards liberalization and the financial market became more competitive. In 1991, the government started selling their shares in the commercial banking sector, and further invited domestic and foreign investors to participate in the banking industry. After liberalization, the number of domestic banks had increased from 24 in 1990 to 53 in 2001 . The average rate of ROE dropped from $20.79 \%$ in 1990 to $3.61 \%$ in 2001 . Non-performing loans rose from $0.93 \%$ of total loans in 1990 to $7.48 \%$ in 2001 (Liu and Hsu, 2006). Bank profits immensely declined due to tough market competition. During the Asian financial crisis, the government underwent several significant reforms in order to solve overbanking problem. For instance, in 2000, the promulgation of Financial Institutions Merger Law provided both tax and non-tax incentives for financial institutions to merge on their own initiative, and to improve the overall operational efficiency and financial soundness within the system. Given the potential benefit of cross-selling, sharing information technology and e-commerce platforms, the financial holding company structure was expected to reduce cost and enhance revenue. As till 2010, 15 FHCs have begun operating in Taiwan and one commercial bank (Chang Hwa Commercial Bank) controlled by majority stock shares of a FHC (Taishin International Financial Holdings) constitute the major component of the domestic financial market. In addition to banks' performance, whether a sound and profitable financial banking system is more sustainable to ensure market stability from any negative shocks, such as the US subprime crisis is essential. This paper uses panel data approach covering more recent period of data from 2005 to 2010 . We subgroup the data into the pre-crisis and post-crisis period based on profitability. The rest of this paper proceeds as following. Section 2 reviews the academic literature. Section 3 is the empirical mode design. Section 4 focuses on CAMEL ratios to explore empirically the determinants of bank performance. Section 5 gives the concluding remarks. 


\section{Literature Review}

The Financial Holding Companies (FHCs) is a financial institution engaged in nonbanking activities, offering customers a wide range of financial services. In 1999, the passage of Gramm-Leach-Bliley Act (GLBA) allowed commercial banks, investment banks, securities firms, and insurance companies to consolidate for the US banking industry. Since then, FHCs and their subsidiaries integrated to engage in a host of new activities like brokerage, advisory, and underwriting. Whether establishing or joining in a FHCs is more profitable remains an important issue in empirical studies. For example, the "synergy hypothesis" suggests that joining in or establishing a FHCs, subsidiaries under them may have the potential to possess lower costs due to cooperative efforts, and to increase economics of scale and scope through cross-selling, resource sharing and efficient capital allocation. This would save customers considerable time and effort; perhaps even less transaction costs, compared to shopping from specialty firms. On the contrary, the alternative view which claims that independent banks (those not subordinated under FHCs) if standing firm on their core banking business, would secure specialization advantages and lower systematic risks. We propose this as the "specialization view". Regarding "synergy hypothesis", those in favor of the include Kwan (1998), who documents that Section 20 subsidiaries are typically more risky and not necessarily more profitable than their commercial bank affiliates and concludes possibly that some diversification benefits may exist for commercial banks because of the low return correlation between securities and bank subsidiaries. Mishkin (1999) and Berger et al. (1999) point out the financial consolidation across activities might lower the portfolio risk and the likelihood of financial firm failure. DeYoung and Roland (2001)find that revenue volatility and a higher degree of total leverage increase with a shift toward fee-based activities for commercial banks, implying greater earnings volatility. Shen and Chang (2007) compare the CAMEL indicators between samples of banks subordinated under FHCs and Independent banks in Taiwan for periods 2002-2006, with consideration to the ceteris paribus condition and also mitigating the sample selection bias. They discover that, on average, banks subordinated under FHCs outperform independent banks on indicators such as the capital adequacy, asset quality, earning ability and liquidity. Chang and Elyasiani (2008) investigate whether insurance activities (underwriting and agency) enhance the financial performance of FHCs in the U.S.

Using quarterly panel observations of 510 FHCs over the period of 2003-2005, they reach two results. First, risk-adjusted return of FHCs is positively associated with a shift toward non-interest activities. Second, when disaggregating the sample by FHC size, risk-adjusted return is positively associated with insurance agency activities in small-sized FHCs and positively associated with insurance underwriting activities in large-sized FHCs. Their finding is that both small and large FHCs can reap from diversification benefits as long as they choose the right niche. Lo and Lu (2009) focus on the efficiency of profitability and marketability to evaluate the FHCs' performance in Taiwan. Their results indicate that the large-sized FHCs perform better than small-sized ones, implying that large-sized FHCs generate higher profits due to their large-scaled assets. And in terms of marketability performance, large-sized FHCs also operate better than small-sized ones, which can be explained by the finding that large FHCs can more easily attract the attention of investors with the trend towards the consolidation of financial institutions. Those who don't totally agree with the synergy view are Templeton and Severiens (1992), who investigate 54 bank holding companies from 1979 to 1986 and find diversification (the share of market value not attributed to bank assets) is associated with lower volatility of shareholder equity returns. Morgan and Samolyk (2003) document diversification is not associated with greater returns (ROE or ROA) or reduced risk. Stiroh and Rumble (2005) find evidence that though diversification benefits do exist between FHCs in the U.S., but gains are offset by the increased exposure to non-interest activities, which are much more volatile, but not necessarily more profitable than interest-generating activities. Their findings also show that within FHCs, marginal increases in revenue diversification are not associated with performance, which may reflect either a change in managerial focus or simply the endogenous nature of the diversification decision. In contrast, marginal increases in non-interest income still imply a robust declining relationship with risk-adjusted profits. Chiou (2009) also investigates the determinants of efficiency and productivity changes of banks in Taiwan, and examine whether banks being subordinated to FHCs could really promote their efficiency and productivity. By applying the data envelopment analysis (DEA) approach to calculate for bank efficiency and a total factor productivity index to measure the productivity of banks, the results show that except for pure technical efficiency, other efficiencies and productivity of the banks have not improved because of their establishment or joining in FHCs. On the contrary, it is because of their before existing better efficiency that allow them to establish or join in a FHC in the first place.

Hwang et al. (2009) take into consideration of both financial and non-financial performance indices of 35 
banks in Taiwan. They divide their samples into new and old banks (based on the year founded), and into public and private banks (according to the types of major sponsors). Results show that for the years of 2000 and 2001, privatized government - owned banks with significantly higher financial performance indices than private banks, but both types of banks are not significantly different from each other in non-financial performance indices. As for new and old banks, both are not significantly different from each other in neither financial nor non-financial performance indices. They suggest that in order to increase bank profits, managers should aim to improve its capital structure, solvency and bank management, rather than establishing more bank branches. As the emphasis on non-interest income bears fewer risk and has more future power grows, banks in Taiwan have currently started to expand into the non-interest business in seek of a more profitable source of revenue. Erji et al. (2012) examine the non-interest income, namely fee and commission income, exchange gains, investment revenue and other income. They use bank data from 1992 to 2009 to investigate how non-interest income affects the mean and variation of a bank's profit in Taiwan's banking industry. Research show diversification benefits from declining covariance between net interest income and non-interest income may exist at the aggregate level, but non-interest income also has more variation than net interest income. Their results reject the hypothesis that increasing non-interest income shares will improve profitability and diminish risk. These studies paint a mixed picture about the performance effects of diversification in banking. As banks had initially hoped by joining in or establishing a FHC could realize cross selling synergies, issues which were not foreseen, including system and cultural incompatibilities could have caused perceived synergies failing to materialize. We try to focus on financial determinants that influence bank's profitability.

\section{Data and empirical model design}

Data and Variable Definitions: Given the fact the Subprime Mortgage Crisis has engulfed many countries and is unique in terms of wealth destruction, we divide our samples into two time periods to compare the before and after crisis determinants of banking performance in Taiwan, covering the period from 2005 to 2010. We denote periods 2005-2008 as the "Pre-crisis period" and periods 2008-2010 as the "Post-crisis period" to see the effect of impact. We include 15 FHCs (including observations for Taiwan Financial Holdings for periods 2008-2010, and excluding Waterland Financial Holdings that does not engage in banking activities) and 18 independent banks (including observations for Taiwan Bank for periods 2005-2007) in our sample. In this paper, we employ the CAMEL ratio to investigate the financial determinants that affect banks' performance. The CAMEL ratings system is a method of evaluating the health of credit unions by the National Credit Union Administration (NCUA), which is based upon five critical elements of a credit union's operations. Variables definitions are shown in Table 1.

Table 1: Variable definitions

\begin{tabular}{|c|c|c|}
\hline CAMEL & Code & Definitions \\
\hline Capital Adequacy & CA_CAP & $\begin{array}{l}\text { Tier } 1 \text { and Tier } 2 \text { capital/ } \\
\text { Risk weighted assets and off balance sheet risks }\end{array}$ \\
\hline \multirow{2}{*}{ Asset Quality } & AQ_LOSS & Loan Loss Reserve/Gross Loans \\
\hline & AQ_IML & Impaired Loans/Equity \\
\hline \multirow{2}{*}{$\begin{array}{l}\text { Management } \\
\text { Ability }\end{array}$} & MA_NIE & $\begin{array}{l}\text { Total non-interest expense minus total non-interest operating } \\
\text { income/Total Assets }\end{array}$ \\
\hline & MA_IE & $\begin{array}{l}\text { Total interest expense and total non-interest expense/Total } \\
\text { Assets }\end{array}$ \\
\hline \multirow{2}{*}{$\begin{array}{l}\text { Earning } \\
\text { Profitability }\end{array}$} & EP_INI & Net Interest Income/ Total Assets \\
\hline & EP_FEE & Net Fees and Commissions/Total Assets \\
\hline \multirow{2}{*}{ Liquidity Risk } & LR_LOAN & Net Loans/Total Assets \\
\hline & LR_LA & Liquid Assets/Customer \& Short Term Funding \\
\hline
\end{tabular}

The first element of CAMEL is Capital Adequacy (CA_CAP), which is the standardized requirement in place for banks and other depository institutions. The index determines how much capital is required to be held for a certain level of assets through regulatory agencies, such as the Bank for International Settlements or the Basel Committee. These requirements are put into place to ensure that these institutions are not 
participating or holding investments that increase risk of default and that they have enough capital to sustain operating losses while still honoring withdrawals. Here we use the total capital ratio as our proxy. Total capital ratio is the total capital adequacy ratio under the Basel rules. It measures Tier 1 and Tier 2 capital which includes subordinated debt, hybrid capital, loan loss reserves and the valuation reserves as a percentage of risk weighted assets and off balance sheet risks. This ratio should be at least $8 \%$. This ratio can't be calculated just by looking at the balance sheet, but has to be calculated internally by the bank. At their option, they may publish this number in their annual report. We expect this ratio to have a negative relationship with ROA. Asset Quality is the second element of CAMEL which is generally associated with credit risk and is related to the left-hand side of the bank balance sheet. Bank managers are concerned with the quality of their loans since it provides earnings for the bank. Loan quality and asset quality are two terms with basically the same meaning. Government bonds and T-bills are considered as good quality loans whereas junk bonds, corporate credits to low credit score firms etc. are seen as bad quality loans. Here we utilize the Loan Loss Reserve/Gross Loans ratio and Impaired Loans/Equity ratio as our proxy. Loan Loss Reserve/Gross Loans ratio (AQ_LOSS) indicates how much of the total portfolio has been provided for, but not charged off. It is a reserve for losses expressed as percentage of total loans. Given a similar charge-off policy, the higher the ratio, the poorer the quality of the loan portfolio will be. We expect this ratio to have a negative relationship with ROA.

Impaired Loans/Equity ratio (AQ_IML) is a proxy set for measuring asset quality of the bank, is calculated as impaired loans divided by equity. It has a negative relationship with ROA. Loans and receivables are assessed for the impairment at the end of each reporting period. When there is objective evidence that one or more events that occurred after the initial recognition of the loans and receivables, and estimated future cash flows of the assets will be potentially affected. Changes in the international or local economic conditions may also correlate with the defaults on loan and receivables. When not performing for certain, the carrying amount of loans and receivables are reduced through the use of bad loans allowance account. Once written off, banks will have to make forgoing provisions for the credits deemed uncollectable in order to replenish the allowance accounts, therefore decreasing the net income, or even the retained earnings of the bank. Impairment losses could also occur, if the difference between the asset carrying the amount and the present value of estimated future cash flows less related collaterals and guarantees is negative. Thus, the lower AQ_IML, the higher ROA. Management Ability is the third element of CAMEL which can be seen as the most qualitative aspect in CAMEL rating. It is the act of getting people together to accomplish desired goals and objectives using available resources efficiently and effectively. Management comprises planning, staffing, leading and controlling an organization or effort for the purpose of accomplishing a goal. Although direct measurements of characteristics do not appear on financial statements, we utilize the burden ratio and the expense ratio proposed by Shen \& Chang (2007) as our proxy to account for management ability. The burden ratio (MA_NIE) is defined as total non-interest expense minus total non-interest operating income, and then divided by total assets. We expect this ratio to have a negative relationship with ROA. The expense ratio (MA_IE) is calculated as total interest expense and total non-interest expense divided by total assets. We expect this ratio to have a negative relationship with ROA.

Earning Profitability is the fourth element of CAMEL which describes the profitability of the bank and avoids the volatility of earnings associated with extraordinary items. Many alternative terms for earnings are in common use, but the routine earnings or commodity-based earnings that can be achieved by the application of assets are our main concern here. We utilize Net Interest Income/ Total Assets ratio and Net Fees and Commissions/Total Assets ratio as our proxy. Net Interest Income/ Total Assets (EP_INI) are the net interest income expressed as a percentage of the total balance sheet. The higher this figure, the cheaper the funding or the higher the margin the bank is commanding. Higher margins and profitability are desirable as long as the asset quality is being maintained. We expect this ratio to have a positive relationship with ROA. Net Fees and Commissions/Total Assets (EP_FEE) indicates fixed income opportunities. The higher is the ratio, the higher stability of the bank. We expect this ratio to have a positive relationship with ROA. Liquidity Risk is the fifth element of CAMEL which represents an asset's ability to be sold without causing a significant movement in the price and with minimum loss of value. Liquidity is not only an indication of the bank's ability to meet customer's day to day cash needs and respond to sudden cash withdraw, it also refers to a bank's ability to meet its payment obligations, in terms of possessing sufficient liquid assets. We here use Net Loans/Total Assets ratio and Liquid Assets/Customer and Short Term Funding ratios to account for liquidity. Net Loans/Total Assets (LR_LOAN) depicts the percentage of bank assets are tied up in loans. The higher this ratio, the less liquid this bank will be. We expect this ratio to have a negative relationship with ROA. Liquid Assets/Customer 
and Short Term Funding (LR_LA) is a deposit run off ratio and looks at what percentage of customer and short term funds could be met if they were withdrawn suddenly, the higher this percentage, the more liquid the bank is and less vulnerable to a classic run on the bank. We expect this ratio to have a positive relationship with ROA.

The empirical model: A panel dataset contains observations on multiple entities (individuals), where each entity is observed at two or more points in time. In other words, panel data allows the simultaneous investigation of a system of equations that consider firm-specific characteristics and time changes. By combining time series of cross-section observations, panel data not only gives more informative data and variability, it also causes less collinearity among variables, and allows more degrees of freedom. The methodology employed here is the general panel regression model as below:

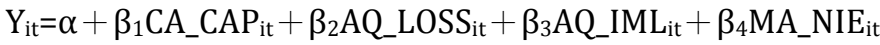

$$
\begin{aligned}
& +\beta_{5} \mathrm{MA}_{-} \mathrm{IE}_{\text {it }}+\beta_{6} \mathrm{EP}_{-} \mathrm{INI} \mathrm{it}_{\mathrm{it}}+\beta_{7} \mathrm{EP}_{-} \mathrm{FEE}_{\text {it }}+\beta_{8} \mathrm{LR}_{-} L O A N_{\text {it }} \\
& +\beta_{9} \mathrm{LR} \_\mathrm{LA} A_{\mathrm{it}}+\varepsilon_{\mathrm{it}}
\end{aligned}
$$

where:

$\mathrm{Y}$ : the dependent variable, here as ROA;

$\mathrm{X}$ : the independent CAMEL variables;

$\alpha$ : the intercept of the regression line;

$\varepsilon$ : the error term;

$\mathrm{i}$ : the subscript $\mathrm{i}$ is the individual dimension and runs over observations, $\mathrm{i}=1, \ldots, n ; n=$ number of entities (banks);

$\mathrm{t}$ : the subscript $\mathrm{t}$ is the time dimension and runs over observations, $\mathrm{t}=1, \ldots, T ; T=$ number of time periods (years).

With panel data, we also control for factors that vary across entities (banks) but do not vary over time, and factors that could cause omitted variable bias if they are omitted. Even if our raw data contains heterogeneity within cross-bank units, the techniques of panel data estimation can take such heterogeneity into account by allowing for individual-specific variables. Different assumptions can be made on the precise structure of the general panel models, the two most recognized are the fixed effects model and the random effects model. The crucial distinction between the term "fixed" and "random" effects is whether the unobserved individual effect embodies elements that are correlated with the regressors in the model. Given a model and data in which fixed effects estimation would be appropriate, a test developed by Hausman and Taylor can determine whether applying random effects estimation would be almost as good. With the random-effects specification, it is assumed that individual effects are not correlated with the regressors, the Hausman test for random effects is as:

$$
\begin{aligned}
& \mathrm{H}_{0}: \mathrm{E}\left(\mathrm{u}_{\mathrm{it}} \mid \mathrm{X}_{\mathrm{it}}\right)=0 \\
& \mathrm{H}_{1}: \mathrm{E}\left(\mathrm{u}_{\mathrm{it}} \mid \mathrm{X}_{\mathrm{it}}\right) \neq 0
\end{aligned}
$$

If the null hypothesis holds, the coefficients under LSDV (the fixed-effects specification) and GLS (the random-effects specification) are consistent and asymptotically efficient, whereas under the alternative hypothesis, only the LSDV is unbiased and consistent. We run the Hausman test and find no systematic deviation in results between the fixed effect model and the random effect model. In other words, the fixed-effect model is much preferred for all models, which may imply the existence of heterogeneity among the banks during both the pre-crisis and post-crisis period. The advantage of applying the fixed effects regression is not only can we control for the unobserved variables that vary across bank units but not over time, but also those that vary over time but not bank units.

\section{Results}

Descriptive statistics: Given the 2007 Subprime Mortgage Crisis is in terms of wealth destruction, we compare the changes and differences of determinants on ROA before and after the financial crisis. Table 2 presents descriptive statistics of the full sample, covering 15 subordinated banks and 18 independent banks in Taiwan. The average of ROA is 0.02 , ranging from 5.83 to -5.55 . The average of the total capital ratio (CA_CAP) is 12.39, ranging from 71.42 to 6.55 . The mean of the impaired ratio (AQ_IML) is about 17.51, ranging from 80.75 to 0.01 . The average of the expense ratio (MA_IE) is 0.03 , and the average of the net interest income ratio (EP_INI) is 1.39. The net loans ratio (LR_LOAN) has a mean of 59.76, ranging 
from 82.74 to 2.60 .

Table 2: Descriptive Summary of the Full Sample

\begin{tabular}{lllll}
\hline Variable & Mean & $\begin{array}{l}\text { Standard } \\
\text { Deviation }\end{array}$ & Maximum & Minimum \\
\hline ROA (\%) & 0.02 & 1.39 & 5.83 & -5.55 \\
CA_CAP (\%) & 12.39 & 6.07 & 71.42 & 6.55 \\
AQ_LOSS (\%) & 1.39 & 0.94 & 6.76 & 0.12 \\
AQ_IML (\%) & 17.51 & 15.53 & 80.75 & 0.01 \\
MA_NIE (\%) & 0.01 & 0.01 & 0.09 & -0.05 \\
MA_IE (\%) & 0.03 & 0.01 & 0.09 & 0.01 \\
EP_INI (\%) & 1.39 & 0.76 & 5.77 & 0.12 \\
EP_FEE (\%) & 0.01 & 0.01 & 0.01 & 0.00 \\
LR_LOAN (\%) & 59.76 & 14.58 & 82.74 & 2.60 \\
LR_LA (\%) & 23.20 & 16.81 & 139.13 & 5.71 \\
\hline NOte: CA_CAP is the totalcapital & & &
\end{tabular}

Note: CA_CAP is the total capital ratio that is defined under the Basel rules. AQ_LOSS is calculated as loan loss reserve divided as gross loans. AQ_IML is calculated as impaired loans divided by equity. MA_NIE is the burden ratio, which is calculated as total non-interest expense minus total non-interest operating income and then divided by total assets. MA_IE is the expense ratio, which is calculated as total interest expense and total non-interest expense divided by total assets. EP_INI is calculated as net interest income divided by total assets. EP_FEE is calculated as net fees and commissions divided by total assets. LR_LOAN is calculated as net loans divided by total assets. LR_LA is calculated as liquid assets divided by customer and short term funding.

The empirical results: Table 3 and Figure 1 depict the change of ROA for subordinated banks and independent banks respectively. Subordinated banks in Taiwan have ROA of 0.35, -0.26, 0.62, $-0.07,0.15$ and 0.65 from 2005 to 2010, which all outperformed independent banks and achieved an overall ROA mean of 0.24 .

Table 3: ROA (from 2005 to 2010)

\begin{tabular}{llllllll}
\hline ROA & & & & & & \\
Full sample & $\mathbf{2 0 0 5}$ & $\mathbf{2 0 0 6}$ & $\mathbf{2 0 0 7}$ & $\mathbf{2 0 0 8}$ & $\mathbf{2 0 0 9}$ & $\mathbf{2 0 1 0}$ & Overall \\
\hline Mean & 0.30 & -0.31 & 0.01 & -0.42 & 0.05 & 0.47 & 0.02 \\
St. Dev. & 1.29 & 1.94 & 1.69 & 1.20 & 1.18 & 0.76 & 1.39 \\
Maximum & 5.15 & 5.83 & 3.46 & 0.77 & 2.46 & 2.99 & 5.83 \\
Minimum & -2.69 & -5.15 & -5.55 & -5.52 & -4.76 & -2.57 & -5.55 \\
Subordinated & 2005 & 2006 & 2007 & 2008 & 2009 & 2010 & Overall \\
Banks & & & & & & & \\
Mean & 0.35 & -0.26 & 0.62 & -0.07 & 0.15 & 0.65 & 0.24 \\
St. Dev. & 1.81 & 2.48 & 1.13 & 0.73 & 1.13 & 0.67 & 1.43 \\
Maximum & 5.15 & 5.83 & 3.46 & 0.77 & 2.46 & 2.99 & 5.83 \\
Minimum & -2.69 & -5.15 & -0.96 & -1.63 & -3.31 & 0.18 & -5.15 \\
Independent & 2005 & 2006 & 2007 & 2008 & 2009 & 2010 & Overall \\
Bank & & & & & & & \\
Mean & 0.26 & -0.36 & -0.52 & -0.73 & -0.05 & 0.30 & -0.18 \\
St. Dev. & 0.62 & 1.40 & 1.94 & 1.46 & 1.25 & 0.82 & 1.34 \\
Maximum & 1.35 & 1.39 & 1.34 & 0.72 & 0.94 & 1.12 & 1.39 \\
Minimum & -1.45 & -4.51 & -5.55 & -5.52 & -4.76 & -2.57 & -5.55 \\
\hline
\end{tabular}

Table 4 shows the correlation matrix. Two variables with a correlation coefficient of -0.73 , namely, LR_LOAN and LR_LA, are highly correlated. To diminish multicollinearity, we substitute one variable for the other. Lastly, using the Hausman test we find no systematic deviation in results between the fixed effect model and the random effect model. 
Figure 1: Comparison of Subordinated and Independent banks

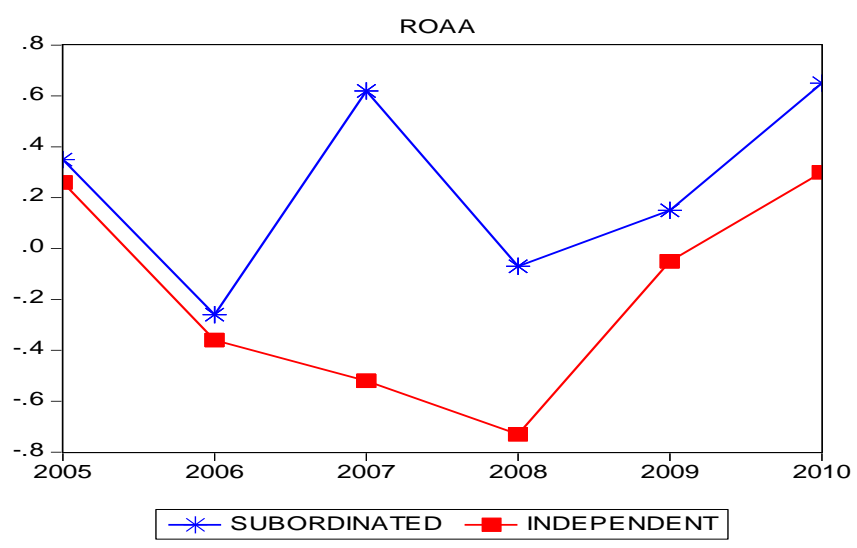

Table 4: Correlation matrix

\begin{tabular}{llllllllll}
\hline & CA_CAP & AQ_LOSS & AQ_IML & MA_NIE & MA_IE & EP_INI & EP_FEE & LR_LOAN & LR_LA \\
\hline CA_CAP & 1.00 & 0.47 & -0.41 & -0.30 & -0.10 & -0.12 & 0.00 & -0.57 & 0.72 \\
AQ_LOSS & 0.47 & 1.00 & 0.03 & 0.23 & 0.36 & 0.45 & 0.20 & -0.26 & 0.25 \\
AQ_IML & -0.41 & 0.03 & 1.00 & 0.20 & 0.33 & 0.15 & -0.11 & 0.49 & -0.35 \\
MA_NIE & -0.30 & 0.23 & 0.20 & 1.00 & 0.63 & 0.51 & 0.18 & 0.25 & -0.34 \\
MA_IE & -0.10 & 0.36 & 0.33 & 0.63 & 1.00 & 0.58 & 0.35 & 0.14 & -0.13 \\
EP_INI & -0.12 & 0.45 & 0.15 & 0.51 & 0.58 & 1.00 & 0.45 & 0.17 & -0.30 \\
EP_FEE & 0.00 & 0.20 & -0.11 & 0.18 & 0.35 & 0.45 & 1.00 & -0.08 & -0.11 \\
LR_LOAN & -0.57 & -0.26 & 0.49 & 0.25 & 0.14 & 0.17 & -0.08 & 1.00 & -0.73 \\
LR_LA & 0.72 & 0.25 & -0.35 & -0.34 & -0.13 & -0.30 & -0.11 & -0.73 & 1.00 \\
\hline
\end{tabular}

Note: CA_CAP is the total capital ratio defined under the Basel rules. AQ_LOSS is calculated as loan loss reserve divided as gross loans. AQ_IML is calculated as impaired loans divided by equity. MA_NIE is the burden ratio, which is calculated as total non-interest expense minus total non-interest operating income and then divided by total assets. MA_IE is the expense ratio, which is calculated as total interest expense and total non-interest expense divided by total assets. EP_INI is calculated as net interest income divided by total assets. EP_FEE is calculated as net fees and commissions divided by total assets. LR_LOAN is calculated as net loans divided by total assets. LR_LA is calculated as liquid assets divided by customer and short term funding.

Table 5 shows the empirical results for full sample. The total capital ratio (CA_CAP) and Loan Loss Reserve/Gross Loans (AQ-LOSS) are significant at $1 \%$ for the entire and pre- and post-crisis periods. The burden ratio (MA_NIE) calculated as total non-interest expense minus total non-interest operating income and then divided by total assets, a proxy set for measuring management of the bank has negative significance in explaining profitability performance for the entire and post-crisis periods. It has the implication of saving a dollar equals to earning a dollar for all banks. Two management ability factors, the burden ratio (MA_NIE) and the expense ratio (MA_IE), are critical, especially in post-crisis period. Two assets-based earnings profitability determinants, EP_INI and EP_FEE, are significant as expected in the post-crisis period. 
Table 5: Empirical results for full sample

\begin{tabular}{llll}
\hline & $\mathbf{2 0 0 5 - 2 0 1 0}$ & Pre-crisis & Post-crisis \\
\hline C & -1.961 & -0.858 & -1.038 \\
CA_CAP & $0.155^{* * *}$ & $0.132^{* * *}$ & $0.107^{* * *}$ \\
& $(0.029)$ & $(0.048)$ & $(0.028)$ \\
AQ_LOSS & $-0.398^{* * *}$ & $-0.570^{* * *}$ & $-0.449^{* * *}$ \\
& $(0.103)$ & $(0.162)$ & $(0.128)$ \\
AQ_IML & -0.003 & -0.011 & $0.017^{* * *}$ \\
& $(0.007)$ & $(0.016)$ & $(0.006)$ \\
MA_NIE & $-70.924^{* * *}$ & -25.603 & $-97.516^{* * *}$ \\
& $(8.209)$ & $(17.171)$ & $(10.825)$ \\
MA_IE & -12.567 & $-68.676^{* * *}$ & $-35.415^{* * *}$ \\
& $(9.574)$ & $(24.899)$ & $(9.438)$ \\
EP_INI & $0.300^{* *}$ & 0.196 & $0.950^{* * *}$ \\
& $(0.135)$ & $(0.323)$ & $(0.200)$ \\
EP_FEE & 45.182 & 80.222 & $120.201^{* * *}$ \\
& $(57.409)$ & $(107.836)$ & $(44.592)$ \\
LR_LOAN & 0.014 & 0.031 & -0.001 \\
R-squared & $(0.015)$ & $(0.027)$ & $(0.015)$ \\
Adjusted R-squared & 0.83 & 0.87 & 0.96 \\
\hline Note: 1* & 0.78 & 0.77 & 0.94 \\
\hline
\end{tabular}

Note: $1{ }^{*}, * *$ and $* * *$ indicate statistical significance at the $10 \%, 5 \%$, and $1 \%$ level. Standard deviations are shown in parentheses. 2. CA_CAP is the total capital ratio defined under the Basel rules. AQ_LOSS is calculated as loan loss reserve divided as gross loans. AQ_IML is calculated as impaired loans divided by equity. MA_NIE is the burden ratio, which is calculated as total non-interest expense minus total non-interest operating income and then divided by total assets. MA_IE is the expense ratio, which is calculated as total interest expense and total non-interest expense divided by total assets. EP_INI is calculated as net interest income divided by total assets. EP_FEE is calculated as net fees and commissions divided by total assets. LR_LOAN is calculated as net loans divided by total assets.

Table 6 and Table 7 show the panel data model results for the subordinated banks and the independent banks respectively. CA_CAP is defined as the total capital ratio, which is the total capital adequacy ratio under the Basel rules. The ratio is designed to ensure banks hold enough resources to absorb external shocks to the balance sheets. If CA_CAP shall fall, the appropriation of earnings as cash dividends or other assets will be restricted, other than discipline of authorities to the banks. In accordance with legal regulations proposed by government officials, raising the CA_CAP may enable new lines of products services, obtain permits to investment overseas, and even the ability to merge and acquire other companies. Thus, our result of positive significant post-crisis CA_CAP ratio confirms that after the financial crisis, such events may enhance and upgrade the bank's overall operating performance for subordinated banks. The asset quality factor, loan loss reserve divided by gross loans ration (AQ-LOSS), is critical as well. As predicted, this ratio is significant negative with ROA for both types of banks in the pre-crisis-period. Nevertheless, our result shows that subordinated banks have better quality of loan portfolios after the crisis, possibly due to more risk- diversification effects. As loan loss reserve ratio is no longer an important factor. The rest of CAMEL elements, such as MA_NIE, MA_IE and EP_INI, appear to be important financial determinants in the post-crisis period for both subordinated and independent banks. 
Table 6: Empirical results of subordinated banks

\begin{tabular}{|c|c|c|}
\hline & Pre-crisis & Post-crisis \\
\hline $\mathrm{C}$ & -5.455 & -3.505 \\
\hline \multirow[t]{2}{*}{ CA_CAP } & 0.086 & $0.118^{* * *}$ \\
\hline & $(0.086)$ & $(0.034)$ \\
\hline \multirow[t]{2}{*}{ AQ_LOSS } & $-1.569 * * *$ & -0.244 \\
\hline & $(0.536)$ & $(0.180)$ \\
\hline \multirow[t]{2}{*}{ AQ_IML } & $-0.076^{*}$ & $0.027^{* * *}$ \\
\hline & $(0.041)$ & $(0.009)$ \\
\hline \multirow[t]{2}{*}{ MA_NIE } & -221.419 & $-117.498^{* * *}$ \\
\hline & $(129.667)$ & $(15.512)$ \\
\hline \multirow[t]{2}{*}{ MA_IE } & 102.643 & $-49.664^{* * *}$ \\
\hline & $(89.115)$ & $(12.756)$ \\
\hline \multirow[t]{2}{*}{ EP_INI } & $1.497^{*}$ & $1.230^{* * *}$ \\
\hline & $(0.788)$ & $(0.307)$ \\
\hline \multirow[t]{2}{*}{ EP_FEE } & -5.414 & 68.401 \\
\hline & (183.651) & $(115.671)$ \\
\hline \multirow[t]{2}{*}{ LR_LOAN } & 0.057 & 0.033 \\
\hline & $(0.044)$ & $(0.022)$ \\
\hline R-squared & 0.88 & 0.97 \\
\hline Adjusted R-squared & 0.75 & 0.94 \\
\hline
\end{tabular}

Note: $1^{*}{ }^{* *}$ and ${ }^{* * *}$ indicate statistical significance at the $10 \%, 5 \%$, and $1 \%$ level. Standard deviations are shown in parentheses. 2. CA_CAP is the total capital ratio defined under the Basel rules. AQ_LOSS is calculated as loan loss reserve divided as gross loans. AQ_IML is calculated as impaired loans divided by equity. MA_NIE is the burden ratio, which is calculated as total non-interest expense minus total non-interest operating income and then divided by total assets. MA_IE is the expense ratio, which is calculated as total interest expense and total non-interest expense divided by total assets. EP_INI is calculated as net interest income divided by total assets. EP_FEE is calculated as net fees and commissions divided by total assets. LR_LOAN is calculated as net loans divided by total assets. 
Table 7: Empirical results of independent banks

\begin{tabular}{|c|c|c|}
\hline & Pre-crisis & Post-crisis \\
\hline $\mathrm{C}$ & -1.785 & 0.229 \\
\hline \multirow[t]{2}{*}{ CA_CAP } & 0.213 & 0.020 \\
\hline & $(0.128)$ & $(0.054)$ \\
\hline \multirow[t]{2}{*}{ AQ_LOSS } & $-0.554^{* *}$ & $-0.478^{* *}$ \\
\hline & $(0.203)$ & $(0.172)$ \\
\hline \multirow[t]{2}{*}{ AQ_IML } & 0.001 & 0.015 \\
\hline & $(0.013)$ & $(0.009)$ \\
\hline \multirow[t]{2}{*}{ MA_NIE } & -35.972 & $-82.119 * * *$ \\
\hline & $(27.816)$ & $(15.588)$ \\
\hline \multirow[t]{2}{*}{ MA_IE } & $-58.019 * *$ & $-49.758^{* * *}$ \\
\hline & $(26.361)$ & $(14.890)$ \\
\hline \multirow[t]{2}{*}{ EP_INI } & 0.318 & $0.902^{* *}$ \\
\hline & $(0.579)$ & $(0.326)$ \\
\hline \multirow[t]{2}{*}{ EP_FEE } & -78.953 & $110.310^{* *}$ \\
\hline & (169.037) & $(53.642)$ \\
\hline \multirow[t]{2}{*}{ LR_LOAN } & 0.027 & 0.004 \\
\hline & $(0.037)$ & $(0.023)$ \\
\hline R-squared & 0.94 & 0.97 \\
\hline Adjusted R-squared & 0.88 & 0.95 \\
\hline
\end{tabular}

Note: $1{ }^{*},{ }^{* *}$ and ${ }^{* *}$ indicate statistical significance at the $10 \%, 5 \%$, and $1 \%$ level. Standard deviations are shown in parentheses. 2. CA_CAP is the total capital ratio defined under the Basel rules. AQ_LOSS is calculated as loan loss reserve divided as gross loans. AQ_IML is calculated as impaired loans divided by equity. MA_NIE is the burden ratio, which is calculated as total non-interest expense minus total non-interest operating income and then divided by total assets. MA_IE is the expense ratio, which is calculated as total interest expense and total non-interest expense divided by total assets. EP_INI is calculated as net interest income divided by total assets. EP_FEE is calculated as net fees and commissions divided by total assets. LR_LOAN is calculated as net loans divided by total assets.

Shen and Chang (2007) propose in their paper to investigate whether subordinated banks have higher performance than the independent ones in Taiwan. They propose 15 variables in total and among them 4 variables are in common with ours, namely the capital adequacy ratio, burden ratio, expense ratio and the net interest income divided by total assets ratio. Their results show that the capital adequacy ratio and burden ratio are both significant variables, while the former has a positive relationship and the latter a negative relationship with the bank's performance. In their sample period starts from 2002 to 2006, they further show subordinated banks have higher average capital adequacy ratios than the independent banks do, and independent banks have lower average burden ratios than subordinated banks do. We find that the subordinated banks have significantly positive asset quality ratios effects in the pos-crisis period, confirming what Shen and Chang (2007) find. In addition, before crisis, burden ratio is not a critical determinant for subordinated banks. In other words, they have better quality of loans than those of independent banks. Contrast to what Shen and Chang (2007) find, our results show that the expense ratio has significant negative relationship with the bank's performance for full sample of banks and subset of independent banks in both 
periods in addition to subordinated banks during the period of 2007-2010. We posit that the discrepancy might be due to the different time periods in sample. Net fees and commissions divided by total assets (EP_FEE) is significantly positive after the crisis for the independent banks. The possibility not observing lucrative fee charge appears to be an important factor in the subordinated banks in Taiwan might be tough market competition.

\section{Conclusion}

The major findings in the paper are as follows. First, our results confirm what Shen and Chang (2007) find and the positive significant capital adequacy ratio in the post-crisis period in our sample is mainly driven by subordinated banks. One plausible explanation is though higher reserving requirements is at the expense of banks, subordinated banks in Taiwan form risk weighted subordinated debt, hybrid capital and off-balance sheet asset through more diversified function nature of business. Second, asset quality factor has explaining power for the pre-crisis and post-crisis periods, meaning prevention safety net built predominantly for independent banks in refraining from external shocks. Third, net fees and commissions divided by total assets (EP_FEE) accounts for the major recovery after the crisis for the independent banks. The interpretation for not observing this earning profitability explaining power in the subordinated banks in Taiwan may be offsetting sunk costs. Ironically, engaging in the wealth management business may not be quite so cost-effective in Taiwan due to market saturation and tough competition. Results show that ROA is strongly related to certain CAMEL ratios, such as the total capital ratio (CA_CAP), loan loss reserve/gross loans (AQ-LOSS), the burden ratio (MA_NIE), and net interest income divided by total assets (EP_INI). Our managerial suggestions for banks in pursuit of profitability on assets include distributing less cash dividends and retain more earnings within the bank, or using capital injections to plenitude the capital adequacy ratio. As for lowering the burden ratio and net interest income to total assets ratio, choosing the right market niche and playing to one's strength is winning strategy. Emphasis on the cost-benefit analysis to reduce unnecessary costs and those that do not generate proportionate and apparent profits is bottom line to stay competitive in the market. Reducing the impaired loans to equity ratio and the loans to total assets ratio may improve ROA at the cost of detaining the net interest income to total assets ratios, thus consequently offset the intended effects. One managerial insight for the variables mentioned above, is much needed careful assessment when approving loans, that is, taking collateral and credit risk into consideration to assure the quality of loans.

\section{References}

Berger, A. N., Demsetz, R. S. \& Strahan, P. E. (1999). The Consolidation of the Financial Services Industry: Causes, Consequences, and Implications for the Future. Journal of Banking \& Finance, 23(2-4), 135-194.

Chang, M. S. \& Elyasiani, E. (2008). Product Diversification and Performance in the Financial Industry: FHCs' Expansion into the Insurance Activities. Meeting of ARIA in Portland.

Chiou, C. C. (2009). Effects of Financial Holding Company Act on Bank Efficiency and Productivity in Taiwan. Neurocomputing, 72(16-18), 3490-3506.

DeYoung, R. \& Roland, K. P. (2001). Product Mix and Earnings Volatility at Commercial Banks: Evidence from a Degree of Total Leverage Model. Journal of Financial Intermediation, 10(1), 54-84.

ErJi, Y., Cheng, M. C., Lee, C. C. \& Chen, I. J. (2012). Diversification in Banking: Is the Non-interest Income the Answer? The Case of Taiwan Banking Industry. Journal of Business and Policy Research, 7(1), 1-29.

Hwang, D. Y., Lee, A. C., Liu, C. C. \& Ouyang, L. (2009). Balance Performance Index and Its Implications: Evidence from Taiwan's Commercial Banks. Review of Pacific Basin Financial Markets and Policies, 12(1), 27-62.

Kwan, S. (1998). Securities Activities by Commercial Banking Firm Section 20 Subsidiaries: Risk, Return, and Diversification Benefits. Economic Letter, Federal Reserve Bank of San Francisco, 98-32.

Liu, W. C. \& Hsu, C. M. (2006). The Benchmark of Financial Development in Economic Growth: The Experiences of Taiwan, Korea and Japan. Journal of Asian Economics, 17(4), 667-690.

Lo, S. F. \& Lu, W. M. (2009). An Integration Performance Evaluation of Financial Holding Companies in Taiwan. European Journal of Operational Research, 198(1), 341-350.

Mishkin, F. S. (1999). Financial Consolidation: Dangers and Opportunities. Journal of Banking \& Finance, 23(2-4), 675-691.

Morgan, D. P. \& Samolyk, K. (2003). Geographic Diversification in Banking and its Implications for Bank Portfolio Choice and Performance. Manuscript, Research and Market Analysis Group, Federal 
Reserve Bank of New York.

Shen, C. H. \& Chang, Y. (2007). Do Financial Holding Company Banks Outperform Independent Banks-Correcting Selection Bias by Matching Methods. The15th Conference on the Theories and Practices of Securities and Financial Markets.

Stiroh, K. J. \& Rumble, A. (2005).The Dark Side of Diversification: The Case of US Financial Holding Companies. Journal of Banking and Finance, 30(8), 2131-2161.

Templeton, W. K. \& Severiens, J. T. (1992). The Effect of Nonbank Diversification on Bank Holding Companies. Quarterly Journal of Business and Economics, 31(4), 3-17. 